\title{
Identifying the balance sheet and lending channels of monetary transmission: A loan-level analysis
}

\author{
Uluc Aysun ${ }^{1}$ \\ University of Central Florida, Orlando \\ Ralf Hepp ${ }^{2,3}$ \\ Fordham University
}

\begin{abstract}
We make a novel attempt at comparing the strength of the lending and balance sheet channels of monetary transmission. To make this comparison, we use loan-level data to determine how borrower balance sheets and bank liquidity are related to bank lending decisions and how monetary policy can affect these relationships. The key innovation in this paper is the use of loan-level data. This enables us to measure the independent effects of the two channels and directly account for borrower balance sheets and lender liquidity instead of using proxies. Our results show that the balance sheet channel is the main mechanism through which monetary policy shocks are transmitted to the economy and that the lending channel does not play a significant role.
\end{abstract}

Keyword(s): balance sheet channel; lending channel; loan-level data; monetary transmission.

JEL Classification: E44; E51; E52; G21

${ }^{1}$ UCF College of Business Administration, 4000 Central Florida Blvd., P.O.Box 161400, Orlando, FL 32816. Email: uaysun@bus.ucf.edu. Homepage: http://www.bus.ucf.edu/faculty/uaysun/

${ }^{2}$ Department of Economics, E-525 Dealy Hall, 441 E. Fordham Rd., Bronx, NY 10458. Email: hepp@fordham.edu. Tel: (+1) 718817 4066. Homepage: http://faculty.fordham.edu/hepp/

${ }^{3}$ We thank Maxim Ulrich for help with the data. We thank Carl Walsh for his valuable suggestions and comments. We also would like to thank Michael Roberts for providing us with a link file that allowed us to match the data from Capital IQ Compustat and Thomson Reuters DealScan. Wharton Research Data Services (WRDS) was used in preparing this paper. This service and the data available thereon constitute valuable intellectual property and trade secrets of WRDS and/or its third-party suppliers. Ralf Hepp gratefully acknowledges the support a Fordham University funded Faculty Research Grant provided to this research. 


\section{Introduction}

The consensus in the monetary economics literature is that monetary policy has a nonnegligible short-run effect (for at least two years) on the real economy. A large number of empirical studies (Romer and Romer, 1989; Bernanke and Blinder, 1992; Christiano et al., 1994) reach this conclusion by using various strategies to identify monetary policy shocks in Structural Vector Auto-regressive (SVAR) models.

The standard cost of capital (or interest rate) channel falls short of explaining this shortrun effectiveness of monetary policy. Research in the past 20 years has, hence, sought alternative explanations. The credit channel theory, or the effect of monetary policy on the level of financial frictions and thus the amount of bank lending, is currently the most prominent explanation and it is supported by empirical evidence (e.g. Bernanke and Gertler, 1995). Studies that investigate how this channel operates by analyzing bank behavior, however, overwhelmingly produce the conflicting result that the response of total loan supply (an indicator of economic activity) to monetary policy shocks is small and has gradually declined over the past 30 years. The decline in this component of the credit channel (more commonly known as the lending channel of monetary transmission) is mostly explained by the easier access to liquidity that banks -- especially larger banks -- have gained together with deeper and more developed financial markets (e.g. Cetorelli and Goldberg, 2010; Kashyap and Stein, 2000). ${ }^{4,5}$ So how exactly does monetary policy affect the economy?

Credit channel theory offers a well-documented, alternative explanation for the nonnegligible effect of monetary policy. According to this theory, monetary policy can also affect

\footnotetext{
${ }^{4}$ den Haan et al. (2007) similarly identify a significant bank portfolio adjustment mechanism and find that the insulation from monetary policy is caused by the counteracting effects of monetary policy on the different components of total loans (real estate versus commercial and industrial).

${ }^{5}$ See Disyatat (2011) for an alternative interpretation of the results in the literature on the bank lending channel.
} 
the amount of lending by having an impact on borrower balance sheets (the value of collateral) and on lender sensitivity to these balance sheets. This channel of monetary transmission (more commonly known as the balance sheet channel), therefore, explains the effectiveness of monetary policy by focusing on the borrower side of financial contracts. Most economists believe that the balance sheet channel is operative, and the mechanism has thus become a common component in macroeconomic models. ${ }^{6}$ Empirical research that measures the strength of this channel, however, is very scarce and to the best of our knowledge, the strength of the lending and the balance sheet channels have not been compared before. This is not surprising. To fully measure the balance sheet channel, one needs loan-level data to identify borrowers and lenders, and link borrower balance sheets and lender liquidity with the terms of the loan contract; these data are not as readily available as bank-level data that are used to measure the lending channel of monetary transmission. Bernanke and Gertler (1995) summarize the difficulty in identifying the independent effects of these channels as follows:

It is extremely difficult to carry out an empirical test that would conclusively separate the bank lending channel from the balance sheet channel. For this reason, we are more confident in the existence of a credit channel in general than we are in our ability to distinguish sharply between the two mechanisms of the credit channel.

In this paper, we use a unique loan-level (commercial and industrial loans) dataset and identify the independent effects of borrower balance sheets and bank liquidity on the lending decisions of banks and investigate how monetary policy affects these decisions. To construct our dataset we first obtain loan-level data such as the spread between the interest rate on the loan and

\footnotetext{
${ }^{6}$ See Bernanke (2007) and Bernanke and Gertler (1995) for a detailed explanation of the lending and balance sheet channels of monetary policy transmission.
} 
a risk free rate (hereafter, the lending spread), the amount and the maturity of the loan from the Thomson Reuters DealScan database. We then combine these data with borrower and lender specific variables that we obtain from the Capital IQ Compustat database. Our dataset covers 15,794 loan deals from 1995 to 2009 . By using this large, loan-level dataset, our paper makes a first attempt at comparing the lending and balance sheet channels of monetary transmission. To clarify our contribution, we should point out that this is certainly not the first empirical investigation of the balance sheet channel. For example, studies such as de Bondt (2004) and Ashcraft and Campello (2007) find that this channel is operative by using proxies for the strength of balance sheets such as average corporate bonds spreads or state GDP gaps. Although these studies usually find that central banks exert a significant effect on the economy through borrower balance sheets, using aggregate variables as proxies for balance sheets does not allow them to fully assess the strength of this channel and to make a comparison with the lending channel. We are also not the first to use loan level data. ${ }^{7}$ To the best of our knowledge, this paper is the first attempt, however, at measuring the strength of the different channels of monetary transmission using loan-level data.

Our results show that balance sheet strength, captured by the borrower leverage ratio, is a significant and important determinant of lending spreads. We find, for example, that lending spreads increase by 0.85 basis points on average when the leverage ratio increases by one percentage point. In contrast, we find that lender liquidity is not significantly related to lending spreads. Our more central result is that the balance sheet channel of monetary transmission is significant and large in magnitude. A comparison with the lending channel reveals that the

\footnotetext{
${ }^{7}$ The only study that uses a comprehensive dataset on loan deals that we could find was Jimenez et al. (2009). The authors use data from the Banco de España and the supervisory agency Central de Información de Riesgos to include credit line-specific, borrower-specific, and lender-specific variables in their dataset. We could not find comprehensive data for U.S. loan deals. However, we should note that there are a number of survey based studies that analyze the determinants of corporate credit lines in the U.S. (Ham and Melnik, 1987; Melnik and Plaut, 1986; Berger and Udell, 1995; Morgan, 1998).
} 
balance sheet channel is also the main way in which monetary policy affects bank lending. For example, we find that a one percent orthogonal shock to non-borrowed reserves growth (captured by the Strongin (1995) index) increases the sensitivity to balance sheets by approximately 0.34 percent. The corresponding effect of monetary policy on the sensitivity to lender liquidity is only 0.007 percent and is insignificant. These results confirm the usual finding in the literature that the lending channel of monetary transmission is insignificant; but, more importantly, they show that monetary policy changes the course of the economy mainly through its effect on borrower balance sheets.

To obtain these results we follow a two-step approach. First, we use quarterly cross section data to measure the sensitivity of lending spreads to the indicators of borrower leverage and lender liquidity. We measure these sensitivities for each quarter in our dataset. Second, we stack the sensitivity coefficients obtained in the first stage to form a time series. We do this separately for the lender liquidity and borrower leverage coefficients. We then measure the effect of monetary policy on these sensitivities in a second stage regression. We also follow this twostep estimation strategy by including different indicators of monetary policy stance and by accounting for first stage measurement errors. Finally, we check the robustness of our benchmark results to using a single stage estimation methodology. The results are similar.

The main advantage of using a loan-level dataset is that it allows us to control for lender liquidity and thus shut down the lending channel. As explained later in the paper, however, our baseline methodology restricts our dataset by excluding banks for which financial information could not be obtained from the Capital IQ Compustat database (e.g. foreign banks). To overcome this shortcoming, we follow an alternative methodology to measure the balance sheet channel. Specifically, we use data from banks that lend more than once in each quarter and compare the 
lending spreads and borrower leverage on these loans. This is similar, in spirit, to the methodology in Ashcraft and Campello (2007). This identification strategy allows us to fully control for lender liquidity, obtain a more pure measure of the balance sheet channel and use more observations, but it does not allow us to make a comparison with the lending channel. We do, however, find that the balance sheet channel is similarly significant and large in magnitude.

The rest of the paper is organized as follows: Section 2 presents the theoretical framework that illustrates the balance sheet and lending channels of monetary transmission. Section 3 discusses our two-step empirical methodology. Section 4 describes the dataset and Section 5 presents our baseline results. Section 6 checks the robustness of our results and compares the strength of the two channels. Section 7 concludes.

\section{Theoretical framework}

The transmission of monetary policy shocks to the real economy through the lending and balance sheet channels of monetary transmission is explained by asymmetric information costs in credit markets (e.g. Bernanke and Gertler, 1995). More specifically, asymmetric information between a borrower and a lender generates a wedge between the risk free rate and borrowing costs (the lending spread) when state verification is costly and monetary policy affects the economy by having an impact on this wedge. According to the balance sheet and lending channels, monetary policy shocks are amplified by their countercyclical effects on borrower leverage and lender liquidity constraints and thus on lending spreads.

Models that include these asymmetric information costs derive a positive relationship between borrower leverage and lending rates (e.g. Bernanke et al., 1999; Carlstrom and Fuerst, 1997; Townsend, 1979). Let $R_{t}^{b}$, lev $v_{t}$ and $R_{t}^{l}$ denote lending rates, borrower leverage and the 
lenders' costs of raising loanable funds, respectively, this relationship can be represented as follows:

$R_{t}^{b}=v\left(\operatorname{lev}_{t}\right) R_{t}^{l} \quad v^{\prime}()>$.

Note that these studies mostly focus on the macroeconomic implications of balance sheets by shutting down the lending channel and assuming that the lenders' costs of raising loanable funds are equal to the risk free rate. Recently, and especially during and after the recent financial crisis, researchers have incorporated similar financial frictions in theoretical models to provide a more realistic representation of financial institutions' cost of borrowing. In these studies, financial frictions or asymmetric information costs generate a negative relationship between lenders' liquidity and their costs of raising loanable funds. Gertler and Kiyotaki (2010), for example, assume that banks face a borrowing premium because they can fail with a positive probability. In their model, banks fail because bank owners divert funds to their families. Let $R_{t}^{l}, l q_{t}$ and $R_{t}^{f}$ denote the lenders' costs of raising loanable funds, lender liquidity and the risk free rate, respectively. This relationship can be represented as follows:

$R_{t}^{l}=\theta\left(l q_{t}\right) R_{t}^{f} \quad \theta^{\prime}()<$.

Combining equations (1) and (2) and a linearization produce the following relationship between borrower leverage, lender liquidity and the lending spread.

$\tilde{R_{t}^{b}}-\tilde{R_{t}^{f}}=\alpha^{b s} \tilde{l e v}+\alpha^{l} \tilde{l q}_{t}$ 
where the variables represent deviations from their steady state values. ${ }^{8}$

In this paper we estimate the sensitivities of lending spreads to borrower leverage and lender liquidity by using loan-level data and we measure the impact of monetary policy on these sensitivity coefficients. It is important to note that analyzing monetary policy in a New Keynesian general equilibrium model that includes borrower and lender balance sheets would allow us to capture the full impact of monetary policy. Although we can embed the relationship in equation (3) in a model with these characteristics to measure the strength of monetary transmission, there are two main reasons why we do not follow this approach. First, the usefulness of New Keynesian models for policy analysis is questioned in the literature. ${ }^{9}$ Second, although the theory that describes the impact of borrower balance sheets on model impulse responses is well established (e.g. Bernanke et al., 1999), the theory that investigates the effect of lender balance sheets is relatively new. Thus the calibration of models with these non-standard features is not well-understood. More importantly, since the monetary transmission mechanism operates through lenders' sensitivity to borrower and lender balance sheets, including these sensitivities as time invariant components in a general equilibrium setting would be subject to the Lucas critique. In our empirical analysis, we instead implicitly assume that monetary policy can impact the sensitivity to borrower balance sheets and lender liquidity. We proceed by describing our empirical methodology.

\section{The empirical model}

${ }^{8}$ Let $\overline{l e v}, \overline{l q}$ and $R^{b}$ denote the steady state values of borrower leverage, lender liquidity and the lending rate, $\alpha^{b s}=v^{\prime}(\cdot) \frac{\overline{l e v}}{R^{b}}$ and $\alpha^{l}=\theta^{\prime}(\cdot) \frac{\overline{l q}}{R^{b}}$

${ }^{9}$ See Chari, Kehoe and McGrattan (2009) for a discussion of the drawbacks to using New Keynesian models for policy analysis. 
Our benchmark empirical approach consists of two stages. In the first stage, we use a cross-section of loan deals data and estimate the following equation for each quarter:

$$
L S_{i j k t}=\beta_{0 t}+\sum_{n=1}^{4} \beta_{n t}^{l e v} l e v_{i t-n}+\sum_{n=1}^{4} \beta_{n t}^{l q} l q_{j t-n}+\chi_{t}^{f} f c_{i t-1}+\chi_{t}^{b} b c_{j t-1}+\chi_{t}^{l} l c_{k t}+e_{i j k t}
$$

where subscripts $i, j, k$ and $t$ represent firm $i$, bank $j$, loan facility $k$ and quarter $t$ that define the loan contract. The variables $L S_{i j k t}$, $l e v_{i t}$, and $l q_{j t}$ denote the lending spread on the loan (see Section 4 for a description), borrower i's total-debt-to-equity ratio (leverage ratio) and lender j's liquid-to-total-assets ratio (liquidity ratio), respectively. $f c_{i t}, b c_{i t}$, and $l c_{k t}$ denote vectors of firm-specific, bank-specific, and loan-specific control variables, respectively. The firm-specific control variables vector includes the log of total assets and the liquid-to-total-assets ratio. The bank specific control variables include the log of total assets and the leverage ratio (measured by total-debt-to-equity). The loan specific control variables include the maturity of the loan and the amount of the loan. We include firm and bank size since it is well-established that bank borrowing constraints are more binding for smaller firms (see for example, Gertler and Gilchrist, 1993) and that the lending channel of monetary transmission operates mainly through smaller banks (e.g. Kashyap and Stein, 2000). Therefore, accounting for size is important for measuring the independent effects of borrower leverage and lender liquidity on lending spreads. In addition, we account for firms' liquidity since it is reasonable to assume that a firm with more liquidity can borrow at lower rates. The reason is that in case of a default, the lender can recover a higher share of the loan and the recovery would be faster when the firm has more liquid assets. It is important to note that we use the firm and bank-specific variables that were reported in the quarter prior to the loan deal to minimize the risks of reverse causality. 
In our estimation we control for the maturity of the loan because time to maturity is usually positively related to risk, and thus lending spreads are found to be higher for loans with longer maturities. Moreover, there is evidence that the relationship between borrower leverage and lending spreads is considerably different for different maturity groups. Specifically, the impact of changes in financial leverage on lending spreads is found to be higher when the maturity is shorter (e.g. Collin-Dufresne, Goldstein and Martin, 2001; Merton, 1974). We also include the amount of the loan since it is found to be negatively related to lending spreads. For example, Smith (1980) shows, using a partial equilibrium model, that an increase in the amount borrowed increases the lender's claim on the assets and thus the value of the debt. Consistent with this theoretical finding, more recent empirical papers (e.g. Chacko et al., 2008; Bao et al., 2011) find that the amount borrowed is an indicator of loan liquidity and thus it is negatively related to lending spreads.

In equation (4) the key coefficients of interest are $\beta_{t}^{\text {lev }}=\sum_{n=1}^{4} \beta_{n t}^{\text {lev }}$ and $\beta_{t}^{l q}=\sum_{n=1}^{4} \beta_{n t}^{l q}$. These coefficients indicate how the strength of borrower balance sheets and lender liquidity are related to the lending spread, respectively. Notice that we include four lags of the borrower leverage and lender liquidity ratios in equation (4). We follow this approach to account for the possibility that lenders consider the leverage of borrowers (as well as their own liquidity position) over a longer time period when formulating the terms of the loan contract.

Note that, by estimating equation (4) separately for each quarter, we are focusing on how lending spreads are related to a cross-section of firms with different leverage ratios and banks with different liquidity ratios. In our second stage estimation, we estimate the impact of timevarying factors such as the U.S. output gap and monetary policy on these sensitivities. To do so, 
we first stack the coefficients $\beta_{t}^{l e v}$ and $\beta_{t}^{l q}$ (estimated separately for each quarter) into the vectors $\Psi_{t}^{l e v}$ and $\Psi_{t}^{l q}$. We then estimate the following two time-series regressions:

$$
\begin{aligned}
& \Psi_{t}^{l e v}=\varsigma+\sum_{k=1}^{8} \gamma_{k}^{b S} m p_{t-k}+\sum_{k=1}^{4} \psi_{k} y_{t-k}+\sum_{k=1}^{3} \theta_{k}^{1} q d_{k}+\tau^{1} T_{t}+v_{t} \\
& \Psi_{t}^{l q}=\phi+\sum_{k=1}^{8} \gamma_{k}^{l} m p_{t-k}+\sum_{k=1}^{4} \lambda_{k} y_{t-k}+\sum_{k=1}^{3} \theta_{k}^{2} q d_{k}+\tau^{2} T_{t}+\eta_{t}
\end{aligned}
$$

where $m p_{t}, y_{t}, q d_{k}$, and $T_{t}$ denote the stance of monetary policy (by construction, an increase in $m p_{t-k}$ indicates a monetary tightening for all the different measures used in this paper), the output gap of U.S. gross domestic product, (seasonal) quarter dummies, and the time trend, respectively. In this model, the impact of monetary policy on the sensitivity to borrower balance sheets and to bank liquidity - i.e. the balance sheet and lending channels of monetary transmission - are captured by the summations, $\gamma^{b s}=\sum_{k=1}^{8} \gamma_{k}^{b s}$ and $\gamma^{l}=\sum_{k=1}^{8} \gamma_{k}^{l}$. We include eight lags of the monetary policy variable since the effect of monetary policy on the economy is typically found to last for at least two years (Bernanke and Blinder, 1992; Christiano et al., 1994). To estimate equations (4), (5), and (6), we use Ordinary Least Squares. We do, however, check the robustness of our benchmark results in Section 6 by accounting for first stage measurement errors in our second stage regressions.

We are following the standard practice in the empirical literature by measuring the balance sheet and lending channels as the impact of monetary policy on the sensitivity to borrower balance sheets and lender liquidity (e.g. Gertler and Gilchrist, 1994; Ashcraft and Campello, 2007; Angelopoulou and Gibson, 2009). It is important to note, however, that the balance sheet channel of monetary transmission not only operates through monetary policy's 
effects on balance sheet and liquidity sensitivities but also through its effect on the strength of the balance sheets and liquidity themselves. Thus by measuring the effect of monetary policy on these sensitivities we are only able to capture one feature of the balance sheet and lending channels. It is extremely difficult to measure the full impact of monetary policy without using a general equilibrium model. We do not follow this approach because of the drawbacks mentioned in Section 2. Our approach, albeit, would not be unreasonable if monetary policy mostly has symmetric effects on the balance sheets and liquidity positions of borrowers and lenders. Throughout the paper, we thus refer to the effect of monetary policy on banks' balance sheet and liquidity sensitivities as the balance sheet and the lending channel, although we are only focusing on one aspect of these channels.

\section{Data}

We obtain quarterly bank and firm specific data from the Capital IQ Compustat database to derive the leverage, liquidity, size, and equity ratios of lenders and borrowers, respectively. The loan-level data that we use in our estimation is from the Thomson Reuters DealScan database. This database not only provides detailed information on commercial loans such as the lending spread, loan maturity, the amount of the loan, and the individual lender shares in multilender loans but more critically allow us to identify the borrower and lender(s) on the loan. To measure the lending spread on the loan, we use the AllInDrawn variable in DealScan. This variable measures the amount the borrower pays in basis points over LIBOR for each dollar drawn down and adds the annual (or facility) fees paid to the bank group, if there are any.

In constructing our dataset, we use the facility start date variable in DealScan to assign every loan (facility) to its corresponding quarter in order to match the loans with the quarterly financial data that we obtain from the Compustat database. In a crucial next step, we match the 
borrowers identified in the DealScan database with their financial statements obtained from the Compustat database. Since these two databases have no common identifying variable, we use a link file generously provided to us by Chava and Roberts (2008). This file links the unique borrower company ID in the DealScan data with the unique gvkey identifier in the Compustat database. The file allows us to link 50,980 loan facilities from 1995Q1 to 2009Q4 to the borrower financial statements in Compustat. To investigate the independent effects of the lending and balance sheet channel, we also match lenders' financial statements with the loan facilities in our sample by using the link file. Doing so, however, reduces our sample size to 32,654 loan facilities. Next, we remove loan facilities that finance mergers and acquisitions, since it is not clear how banks' loan decisions are made in this case. ${ }^{10}$ After removing outliers and observations with missing values or where the shares in a syndicated loan add up to more than 100 percent, our final sample contains data on 15,794 loan facilities (31,352 observations) for the time period from 1995Q1 to 2009Q4. ${ }^{11}$

To check whether using this restricted dataset biases our results, we later use an alternative specification that does not make use of any bank specific data and therefore allows us to make use of all the linked loan facilities. We describe this specification in more detail in Section 6. Finally, we add measures describing the monetary policy stance of the U.S. Federal Reserve bank and add the U.S. output gap. These variables are obtained from the Federal Reserve Economic Data and the Bureau of Economic Analysis databases, respectively.

\footnotetext{
${ }^{10}$ For example, whose balance sheet is taken into account, the acquiring firm's or the firm that is being acquired or both? And if both of them are considered, what relative weights do(es) the lender(s) assign?

${ }^{11}$ The number of loan facilities does not correspond to the number of observations since each loan facility can have more than one lender, i.e., we include syndicated loans. In all of our regressions, we include the loan amount as a control variable. In case of a syndicated loan facility, we define the loan amount of an individual bank as the total loan amount of the syndicated loan facility multiplied by the share that the bank commits to contribute to the loan facility.
} 
Table 1 provides some annual descriptive statistics. One important observation is that the liquidity and leverage ratios have considerably different means and standard deviations. For example, across the sample period, the lender liquidity ratio is much less volatile than borrower leverage. Thus, it is important to account for this disparity when comparing the strength of monetary transmission that operates through lender liquidity and borrower leverage. Note also that although by restricting our sample we exclude approximately two-thirds of the loans and the loan volume (and approximately one-half of the borrowers) in the database, our benchmark dataset includes a non-negligible share of total commercial and industrial loans in the U.S. Specifically, the share of the loans in our (smaller) benchmark sample as a percentage of total loans in the U.S. is, on average, around 2.7 percent during the sample period. Similarly, the total borrower and lender assets are relatively large compared to aggregate U.S. data. ${ }^{12}$ Comparing our sample with the unrestricted sample (the Database column) we observe that the differences in the share of lending by sector, and in the mean liquidity of lenders are small. In the excluded loan deals the lending spreads and borrower leverage are, on average, higher (although both lending spreads fall within the range of values observed in the U.S.). As mentioned above, we had to exclude a considerable share of these loans because we were not able to match Compustat data with the lenders in these loans. In Section 6, we do, however, follow a methodology that does not require lender data and thus we use a broader dataset to measure the significance of the balance sheet channel.

\section{Results}

The first stage estimation results from our benchmark regression are displayed in Table 2.

There are two main findings: First, a majority of the leverage coefficients $\left(\hat{\beta}_{t}^{\text {lev }}\right)$ are significant

\footnotetext{
${ }^{12}$ Note that the database includes foreign borrowers and lenders that are not included in the U.S. data.
} 
(in 49 out of 60 quarters) and have the expected signs (42 out of 49 quarters) indicating a positive relationship between borrower leverage and lending spreads. Second, we find that the coefficient of the liquidity variable $\hat{\beta}_{t}^{l q}$ is negative (consistent with the predictions of the lending channel theory) as often as it is positive and that most of these coefficient values are insignificant (41 out of 60 quarters). The latter finding is consistent with the growing literature showing that bank liquidity is not an important determinant of lending decisions and thus bank lending has now become more insulated from monetary policy's effects on liquidity constraints.

In our second stage regressions we test whether monetary policy has any impact on these sensitivities to borrower leverage and lender liquidity. The results are displayed in Table 3. In these baseline estimations, we use the nominal and real federal funds rates as the measures of monetary policy stance. The coefficient values reported in Table 3 demonstrate that while the balance sheet channel of monetary transmission is alive (column 1), the lending channel is not operating effectively (column 5). Specifically, the positive and significant coefficient values in the first column suggest that when monetary policy is tightened, the sensitivity to borrower leverage increases: i.e., the cost of finance for a firm with a given leverage is higher in an economy facing a monetary tightening. The coefficient value for the nominal federal funds rate of 0.005 in column 1 , for example, indicates when there is a 100 basis points increase in the nominal federal funds rate (uniformly spread over the past 8 quarters), a one percentage point increase in borrower leverage generates a 0.5 percent higher, positive lending spread response. This represents a significant increase in the sensitivity of the lending spread to borrower leverage given that our first stage regressions results indicate that a one percent increase in borrower leverage, on average, increases the lending spread by 0.085 percent. In contrast to these results, 
the coefficient values in column 5 reveal that monetary policy has an insignificant effect on the lending spread sensitivity to bank liquidity.

One advantage of including borrower leverage and lender liquidity in the same model is that it allows us to measure the impact of monetary policy on bank lending via borrower balance sheets independent of its effect on lender liquidity and vice versa. This unique feature of our analysis allows us to compare the strengths of these channels and to determine which channel of monetary transmission is more important. Note, however, that a comparison based on the coefficient values reported in Table 3 can be misleading since the variations in the ratios that proxy borrower leverage and lender liquidity, as displayed in Table 1, are considerably different. We account for these differences by standardizing the two ratios when comparing the strength of the two channels in the next section.

\section{Sensitivity analysis and a comparison of the two channels}

In this section, we check the sensitivity of our results to using alternative measures of monetary policy, we compare the strength of the two channels, we account for first stage measurement errors in our second stage estimations, we measure the balance sheet channel by using a different methodology to shut down the lending channel, and we use a single stage estimation approach.

\section{Alternative measures of monetary policy stance}

The changes in real and nominal federal funds rates are often assumed to indicate whether monetary policy is loose or tight. The changes in these variables, however, may reflect policy responses to various other shocks in the economy such as output and prices. In this section, we use indices that do not include these endogenous components of the federal funds rate and thus provide more refined measures of monetary policy stance. Specifically, we check 
whether our baseline results are robust to using these alternative indices of monetary policy stance. To do so, we use orthogonal shocks to borrowed reserves as well as indices constructed by Christiano and Eichenbaum (1992), Strongin (1995), and Bernanke and Mihov (1998). We follow the methodology described in these papers to extend the indices to 2009Q4 and use these indices throughout Section 6 when checking the robustness of our results and comparing the strength of the two channels. ${ }^{13}$

The results displayed in Table 4 indicate that the relationships between monetary policy and the sensitivities to borrower leverage and lender liquidity are also observed when a broader group of monetary policy measures is used. Specifically, the relationship between monetary tightening and the sensitivity to borrower leverage is positive and significant for all measures of policy stance; the relationship between monetary tightening and the sensitivity to lender liquidity is not statistically significantly different from zero for all alternative monetary policy stance measures. Similar to the results in Table 3, the results in Table 4 indicate that while the balance sheet channel of monetary transmission is effectively operating, the lending channel is not.

\section{Comparing the strength of the two channels}

In our baseline analysis we use the total-debt-to-shareholders'-equity and the liquid-tototal-assets ratios to capture borrower leverage and lender liquidity, respectively. Comparing the coefficient values of these ratios to draw inferences for the relative strengths of the lending and the balance sheet channels of monetary transmission would, however, be difficult given the different characteristics of these ratios. Indeed, while the total-debt-to-shareholders'-equity ratio has a mean value of 181.6 percent and a standard deviation of $1,905.3$ percent, the liquid-tototal-assets ratio has a mean and a standard deviation of 11.3 and 8.9 percent, respectively, in the

\footnotetext{
${ }^{13}$ Bernanke and Mihov (1998) summarize the methodologies that are used to identify monetary policy shocks and generate these indices.
} 
whole sample period. Thus, given that the coefficient values measure the effect of a one percentage point increase in the ratios on lending spreads and since the variation in the leverage ratio is considerably higher, the results understate the importance of borrower balance sheets for monetary transmission.

To make the comparison more meaningful, we standardize the ratios by converting them to variables with a mean of zero and a standard deviation of one. Thus, by construction, the coefficient values are now interpreted as the impact of a one standard deviation change in the ratios on the lending spreads and a comparison of the results is more meaningful.

The monetary policy coefficient values that are estimated in our second stage regressions are displayed in Table 5. The results reveal one of the central findings of this paper. For all the different monetary policy measures, the balance sheet channel of monetary transmission is not only more significant than the lending channel but it is also larger in magnitude. When the monetary policy stance is measured using the Strongin (1995) index, for example, we find that a one percent orthogonal shock to the non-borrowed reserves growth rate increases the sensitivity to balance sheets by approximately 0.34 percentage points. The corresponding effect of monetary policy on the sensitivity to lender liquidity is only 0.00674 percentage points and is insignificant. Together with evidence presented earlier that the lending channel is losing strength, these results suggest that the balance sheet channel of monetary transmission should perhaps receive more consideration in the empirical credit channel literature.

\section{Accounting for first stage measurement errors}

So far we used the mean values of the first stage coefficients, estimated separately for each quarter, in the second stage to measure the balance sheet and lending channels of monetary policy transmission. The main shortcoming of this strategy is that if the first stage measurement 
errors are different for each quarter, the second stage estimators can be inefficient and biased. This is similar to the well-documented generated regressors problem that is caused by including a generated variable as a regressor in a second stage regression. The problem in our estimation takes a different form. The generated variable is the dependent, and not the independent variable in the second stage regression. Thus the usual solutions to the generated regressors problem cannot be applied to our estimation. We account for first stage measurement errors in two ways. First, we use the first stage coefficient standard errors as weights in our second stage estimation. Doing so allows us to assign smaller weights to periods in which the estimation is less accurate. Second, we follow a bootstrap strategy and for each quarter generate 100 random first stage coefficients by using the distribution of these coefficients. We then stack these coefficients to obtain 100 random vectors of the dependent variable. Finally, we estimate the second stage regression using these 100 generated, dependent variable vectors.

The results are displayed in Table 6. The coefficients and the F-statistics are measured as the simple averages across the 100 regressions. The results indicate, consistent with our baseline results, that the balance sheet and lending channels of monetary transmission are significant and insignificant, respectively. We do, however, find that both the balance sheet and lending channel coefficients are larger compared to the baseline results. This finding suggests that monetary transmission may be operating more effectively in the latter periods, since the larger number of observations in the latter periods allows us to estimate the first stage coefficients more accurately, leading to larger assigned weights for these periods.

\section{An alternative method for measuring the balance sheet channel}

We lose approximately 18,000 (out of 50,980) loan facilities by only including banks that have a gvkey (Compustat's unique identifier) and thus can be linked to the Compustat database. 
Aside from decreasing the number of observations, this shortcoming would also cause a bias in our results if the excluded banks do not have characteristics that are similar to the banks in our dataset. Our baseline dataset, for example, does not include loan deals made by foreign banks. Given the disparity in the behavior of foreign and domestic banks and how monetary policy shocks could be transmitted through them (e.g. Cetorelli and Goldberg, 2011; e.g. Berger et al., 2000; Berger et al., 2001; Clarke et al., 2003; Buch, 2005) this omission could be critical. In this section, we measure the balance sheet channel of monetary transmission for the broader group of banks in the Dealscan database. The feature of our alternative identification strategy that allows us to estimate the strength of the balance sheet channel without using bank-level financial data (from Compustat) is the representation of the variables as deviations from their averages computed across bank-level loan deals. Specifically, in each quarter, we identify all the loans that a particular bank makes. We then measure the lending spread, borrower leverage, and firm and loan specific variables as deviations from the average values computed across all the loans of this bank (in a particular quarter). ${ }^{14}$ By measuring these variables as deviations from the mean, we effectively shut down any effect that a bank's liquidity position may have on its loans. In other words, this approach allows us to measure the independent effects of borrower balance sheets on the lending spread. We replace our first-stage regression (4) with the following model to generate this alternative measure of the balance sheet channel for each quarter,

$$
\Delta L S_{i j k t}=\beta_{0 t}+\sum_{n=1}^{4} \beta_{n t}^{l e v} \Delta l e v_{i t-n}+\chi_{t}^{f} \Delta f c_{i k t-1}+\chi_{t}^{l} \Delta l c_{k t}+e_{i j t}
$$

where the variables are measured as deviations from their quarterly (bank-specific) means. The second-stage regressions are identical to regressions (5) and (6). The second-stage regression

\footnotetext{
${ }^{14}$ When performing the first stage regressions (equation (4)), we include a borrower's equity ratio as an additional firm-specific variable.
} 
results displayed in Table 7 show that the balance sheet channel is significant when a broader group of lenders is considered and when an alternative methodology is used to identify this channel. A simple thought experiment uncovers the economic significance of the balance sheet coefficients reported in Table 7. First, assume that there is a one percent orthogonal shock to the non-borrowed reserves growth rate (spread uniformly across the previous 8 quarters). Second, assume that a borrower's leverage is one percent higher than the average leverage of all the other borrowers that borrow from the same bank. The coefficient value of 0.253 reported in column 4 then implies that the lending spread for this borrower increases by 0.253 percent more than that of all the other borrowers.

It is possible to follow a similar methodology to shut down the balance sheet channel. Specifically, one can identify companies that have borrowed from different lenders in a given quarter and shut down the balance sheet channel by comparing the terms of these loans. The number of observations, however, was insufficiently small for obtaining meaningful results.

\section{Single Stage Estimation}

The two-step approach we follow above may be vulnerable to over-parameterization because it imposes fewer parameter restrictions compared to a one-step approach. Furthermore, our two-step approach only allows us to measure the effect of monetary policy on the average level of balance sheet and liquidity sensitivities. In contrast, a one-step approach enables us to exploit the large panel dimension of our data. In this section, we test the robustness of our baseline results by estimating the following single stage regression:

$$
\begin{aligned}
L S_{i j k t}=\beta_{0 t}+\sum_{n=1}^{4} \beta_{n t}^{l e v} l e v_{i t-n}+\sum_{n=1}^{4} & \beta_{n t}^{l q} l q_{i t-n}+\chi_{t}^{f} f c_{i t-1}+\chi_{t}^{b} b c_{j t-1}+\chi_{t}^{l} l c_{k t}+\sum_{k=1}^{8} \gamma_{k} m p_{t-k} \\
& +\sum_{m=1}^{4} \sum_{k=m}^{m+7} \gamma_{m k}^{l e v} l e v_{i t-m} m p_{t-k}+\sum_{m=1}^{4} \sum_{k=m}^{m+7} \gamma_{m k}^{l q} l q_{i t-m} m p_{t-k}+e_{i j k t}
\end{aligned}
$$


We also include lender and season dummies as well as a time trend in equation (8). Table 8 displays the results. We find that borrower leverage, lender liquidity, and monetary policy coefficients have the expected signs for (almost) every alternative measure of monetary policy. Specifically, borrower leverage and monetary tightening are positively and lender liquidity is negatively related to the lending spread. The interactive variables' coefficients indicate, similar to our two-stage estimation, that when there is a monetary tightening, lending spreads are more sensitive to borrower leverage for our alternative monetary policy stance measures and that this channel of monetary transmission is significant. In contrast, we find that the relationship between lender liquidity and lending spread becomes less negative when there is a monetary tightening. Although these results are consistent with our previous findings that monetary transmission operates through the balance sheet channel, it is at first puzzling to find a negative coefficient for lender liquidity. Indeed, the negative coefficient suggests that the lending spread becomes less sensitive to lender liquidity when monetary policy is tightened. There is evidence showing, however, that this negative relationship may be due to a bank portfolio adjustment mechanism (e.g. den Haan et al., 2007). Specifically, banks choose to make more commercial loans when interest rates are high (relative to real estate loans) and thus their commercial loans may not be as sensitive to their liquidity when monetary policy is tightened.

\section{Conclusion}

In this paper, we use a large number of loan-level observations to estimate the importance of the balance sheet and lending channels in monetary policy transmission. The unique feature of our analysis is that by using a loan-level dataset, we are able to identify the independent effects of borrower balance sheets and lender liquidity on monetary transmission. Consistent with 
theory, we find that monetary policy affects the sensitivity of bank lending to borrower balance sheets such that a weak balance sheet position of a borrower increases the lending spread on a bank loan more under tight than under loose monetary policy. In other words, banks' lending decisions are amplified by monetary policy as suggested in the financial accelerator literature (e.g. Bernanke et al, 1999). Furthermore, our finding of a diminished role for the lending channel confirms the results of earlier studies that suggest that financial innovation makes banks less dependent on deposits as a means of raising loanable funds. These results suggest that if monetary policy effectiveness is measured more broadly by using the balance sheet channel in addition to the more common lending channel measures, the usual conclusions in the monetary literature can be reversed: Monetary policy that operates through the broad credit channel is still effective.

Despite the advantage of using a large number of loan-level data, our analysis is not without drawbacks. For example, the reduced form equations that we estimate to draw conclusions for monetary transmission do not allow us to account for the direct effects of monetary policy on borrower balance sheets and lender liquidity. It would be interesting for future research to embed a partial equilibrium framework where it is costly to raise loanable funds into a model that includes borrower balance sheets and effective monetary policy to compare the strength of the different channels. This comparison can be made more meaningful by calibrating the non-standard parameters in the model such as sensitivity to balance sheets and lender liquidity by using the results from a loan-level data analysis such as ours. 


\section{References}

Ashcraft, A., Campello, M., 2007. Firm balance sheets and monetary policy transmission. Journal of Monetary Economics 54, 1515-1528.

Bao, J., Pan., J., Wang, J., 2011. The Illiquidity of Corporate Bonds. Journal of Finance 66, 911946.

Berger, A.N., DeYoung, R., Genay, H., and Udell, G.F., 2000, Globalization of Financial Institutions: Evidence from Cross-Border Banking Performance. Brookings-Wharton Papers on Financial Services 3, 23-158.

Berger, A.N., Klapper, L.F., and Udell, G.F, 2001, The Ability of Banks to Lend to Informationally Opaque Small Businesses, Journal of Banking and Finance 25, 2127-2167.

Berger, A.N., Udell, G.F., 1995. Relationship lending and lines of small firm finance. Journal of Business 68, 355-82.

Bernanke, B.S., 2007. The Financial Accelerator and the Credit Channel. Speech given at the Credit Channel of Monetary Policy in the Twenty-first Century Conference, FRB Atlanta. Available at http://www.federalreserve.gov/newsevents/speech/bernanke20070615a.htm.

Bernanke, B.S., Blinder, A., 1992. The federal funds rate and the channels of monetary transmission. American Economic Review 82, 901-21.

Bernanke, B.S., Gertler M., 1995. Inside the Black Box: The Credit Channel of Monetary Policy Transmission. Journal of Economic Perspectives 9(4), 27-48.

Bernanke, B.S., Gertler, M., Gilchrist, S., 1999. The financial accelerator in a quantitative business cycle framework. In: Taylor, J.B., Woodford, M. (Eds.) Handbook of Macroeconomics, 1341-93. Elsevier.

Bernanke, B.S., Mihov, I., 1998. Measuring Monetary Policy. Quarterly Journal of Economics 113(3), 869-902.

Buch, C.M., 2005, Distance and International Banking, Review of International Economics 13(4), 787-804.

Carlstrom, C.T., Fuerst, T.S., 1997. Agency costs, net worth, and business fluctuations: Acomputable general equilibrium analysis. American Economic Review 87, 893-910.

Cetorelli, N., Goldberg, L.S., 2011. Global Banks and International Shock Transmission: Evidence from the Crisis. IMF Economic Review 59(1), 41-76.

Collin-Dufresne, P., Goldstein, R.S., Martin, S.J., 2001. The determinants of credit spread changes. Journal of Finance 56, 2177-2207.

Chari V. V., Kehoe, P.J., McGrattan, E.R., 2009. New Keynesian Models: Not Yet Useful for Policy Analysis. American Economic Journal: Macroeconomics 1(1), 242-66.

Chacko, G., Mahanti, S., Mallik G., Subrahmanyam, M., 2008. Latent liquidity: A new measure of liquidity with an application to corporate bonds. Journal of Financial Economics 88(2), 272-298.

Chava, S., Roberts, M.R., 2008. How Does Financing Impact Investment? The Role of Debt Covenants. Journal of Finance 63, 2085-2121.

Christiano, L.J., Eichenbaum, M., 1992. Identification and the liquidity effect of a monetary policy shock. In: Cukierman, A., Hercowitz, Z., Leiderman, L. (Eds.), Political economy, growth and business cycles, 335-370. MIT Press: Cambridge and London.

Christiano, L.J., Eichenbaum, M., Evans, C., 1994. The Effects of Monetary Policy Shocks: Evidence from the Flow of Funds. The Review of Economics and Statistics 78(1), 16-34. 
Clarke, G., Cull, R., Martinez Peria, M.S., and Sanchez, S.M., 2003, Foreign Bank Entry: Experience, Implications for Developing Economies, and Agenda for Further Research. The World Bank Research Observer 18, pp. 25-59.

de Bondt, G., 2004. The balance sheet channel of monetary policy: first empirical evidence for the euro area corporate bond market, International Journal of Finance and Economics 9(3), 219-228.

den Haan, W.J., Sumner, S.W., Yamashiro, G.M., 2007. Bank loan portfolios and the monetary transmission mechanism, Journal of Monetary Economics 54, 904-924.

Disyatat, P., 2011. The Bank Lending Channel Revisited. Journal of Money, Credit and Banking 43(4), 711-734.

Gertler, M., Gilchrist, S., 1993. The role of credit market imperfections in the monetary transmission mechanism: arguments and evidence. Scandinavian Journal of Economics 95, 43-64.

Gertler, M., Kiyotaki, N., 2010. Financial Intermediation and Credit Policy in Business Cycle Analysis. In: Friedman, B., Woodford, M. (Eds.), Handbook of Monetary Economics, vol. 3A. Amsterdam, Elsevier, pp. 547-599.

Ham, J.C., Melnik, A., 1987: Loan demand: An empirical analysis using micro data. Review of Economics and Statistics 8, 251-263.

Jiménez G., Lopez, J.A., Saurina, J., 2009. Empirical analysis of corporate credit lines. Review of Financial Studies 22, 5069-5098.

Kashyap, A., Stein, J., 2000. What do a million observations on banks say about the transmission of Monetary Policy? American Economic Review 90, 407-28.

Melnik, A., Plaut, S.E., 1986. Loan commitment contracts, terms of lending and credit allocation. Journal of Finance 41, 425-435.

Merton, R.C., 1974. On the pricing of corporate debt: The risk structure of interest rates. Journal of Finance 29, 449-470.

Morgan, D., 1998. The credit effects of monetary policy: Evidence using loan commitments. Journal of Money Credit and Banking 30, 102-118.

Romer, C., Romer, D., 1989. Does Monetary Policy Matter? A New Test in the Spirit of Friedman and Schwartz. NBER Macroeconomics Annual 4, 121-170.

Smith, C.W., 1980. On the Theory of Financial Contracting. Journal of Monetary Economics 6, 333-357.

Strongin, S., 1995. The identification of monetary policy disturbances: Explaining the liquidity puzzle. Journal of Monetary Economics 34, 463-497.

Townsend, Robert M., 1979. Optimal contracts and competitive markets with costly state verification. Journal of Economic Theory 21(2), 265-293. 
Table 1. Descriptive statistics

\begin{tabular}{|c|c|c|c|c|}
\hline & & Sample & Database & U.S. \\
\hline Avg. number of loan deals per year & & 1,034 & 3,399 & 591,220 \\
\hline Number of lenders & & 186 & 250 & 9,391 \\
\hline Number of borrowers & & 5,006 & 9,264 & \\
\hline \multirow[t]{2}{*}{ Assets (mean, Mil. 2005 USD) } & lender & $11,888,951$ & $13,654,635$ & $18,398,109$ \\
\hline & borrower & $13,279,413$ & $21,549,745$ & $28,873,614$ \\
\hline \multirow[t]{2}{*}{ Borrower leverage $(\%)$} & mean & 180.03 & 211.91 & \\
\hline & standard deviation/mean & 9.64 & 13.71 & \\
\hline \multirow[t]{2}{*}{ Lender liquidity $(\%$, mean $)$} & mean & 11.23 & 11.74 & 8.09 \\
\hline & standard deviation/mean & 0.78 & 0.79 & \\
\hline Lending spread (basis points, mean) & & 168.33 & 202.20 & $209.00^{*}, 142.64^{*}$ \\
\hline Loan volume (mean, Mil. 2005 USD) & & 341,437 & $1,155,542$ & $12,967,340$ \\
\hline Coverage & & $2.72 \%$ & $9.09 \%$ & \\
\hline \multirow[t]{10}{*}{ Share of lending by Industry } & 01-09 Agricul., & $0.3 \%$ & $0.2 \%$ & \\
\hline & 10-14 Mining & $6.9 \%$ & $6.8 \%$ & \\
\hline & 15-17 Construction & $15.4 \%$ & $18.2 \%$ & \\
\hline & 20-39 Manufacturing & $17.2 \%$ & $17.0 \%$ & \\
\hline & $\begin{array}{l}\text { 40-49 Transport., } \\
\text { Comm., Elec., Gas \& }\end{array}$ & $25.4 \%$ & $24.5 \%$ & \\
\hline & 50-51 Wholesale Trade & $8.0 \%$ & $7.0 \%$ & \\
\hline & 52-59 Retail Trade & $16.5 \%$ & $15.2 \%$ & \\
\hline & $\begin{array}{l}\text { 60-67 Finance, } \\
\text { Insurance \& Real Estate }\end{array}$ & $7.3 \%$ & $7.2 \%$ & \\
\hline & 70-89 Services & $1.9 \%$ & $2.0 \%$ & \\
\hline & $\begin{array}{l}\text { 91-99 Public } \\
\text { Administration }\end{array}$ & $1.1 \%$ & $1.7 \%$ & \\
\hline
\end{tabular}

Note: This table provides some descriptive statistics obtained from the dataset used in our regressions, the DealScan database and some statistics summarizing U.S. data. The first row reports the average, annual number of loan deals across the sample period (1995-2009). The number of loan deals in the U.S. is calculated as total value of commercial and industrial (C\&I) loans divided by the mean value of C\&I loans. These data are from the Federal Reserve Bank of St. Louis FRED database. Number of lenders and borrowers in the sample and the Database column represent the total number of unique borrowers and lenders during the sample period. The number of lenders in the U.S. is based on the authors' own calculations using the Federal Reserve's Call Reports of Condition and Income (Cal Report) data and similarly represent the number of unique lenders during the sample period. Total assets of borrowers and lenders represent the total annual number of loans, averaged across the sample period. In the U.S. column, the total assets of the borrowers represent total assets of nonfarm nonfinancial businesses (source: FRED) and the total assets of the lenders are computed using Call Report data. Total assets are converted to real dollars using the GDP deflator. Borrower leverage is measured by the total-debt-to-share-holders'-outstandingequity ratio. Lender liquidity is measured by the total-liquid-assets-to-total-assets ratio. The lender liquidity statistic in the U.S. column is based on the authors' calculations using Call Report data. The lending spread variable in the same and the DealScan database represents the AllInDrawn - the premium over LIBOR for each dollar drawn down. * The lending spread variables in the U.S. column are the BofA Merrill Lynch US Corporate BBB and A OptionAdjusted spreads, respectively. The coverage variable measures the share of US commercial and industrial loans that our dataset covers. The loan volume variable measures the average, annual value of loans across the sample period (the amounts are converted to real 2005 dollars using the GDP deflator prior to averaging). The total loan volume in the U.S. column represents the average, annual value of C\&I loans at all commercial banks (in real 2005 dollars, source: FRED). The share of lending by industry is calculated using data from the DealScan database. 
Table 2. First stage estimation results

\begin{tabular}{|c|c|c|c|c|c|c|c|c|c|c|c|c|c|}
\hline year & quarter & $\beta_{t}^{l e v}$ & F-stat & $\beta_{t}^{l q}$ & F-stat & $\begin{array}{c}\text { number } \\
\text { of obs. }\end{array}$ & year & quarter & $\beta_{t}^{l e v}$ & F-stat & $\beta_{t}^{l q}$ & F-stat & $\begin{array}{c}\text { number } \\
\text { of obs. }\end{array}$ \\
\hline \multirow[t]{4}{*}{1995} & 1 & -0.27 & 4.91 & -0.21 & 0.84 & 143 & 2003 & 1 & 0.11 & 4.87 & 3.16 & 0.72 & 190 \\
\hline & 2 & -0.13 & 12.30 & -1.68 & 1.25 & 260 & & 2 & 0.15 & 6.77 & 1.43 & 0.89 & 318 \\
\hline & 3 & 0.17 & 2.49 & -2.39 & 0.82 & 124 & & 3 & 0.37 & 11.50 & -3.22 & 1.56 & 211 \\
\hline & 4 & 0.10 & 7.23 & 0.51 & 2.09 & 200 & & 4 & 0.16 & 7.01 & -2.91 & 1.05 & 299 \\
\hline \multirow[t]{4}{*}{1996} & 1 & 0.17 & 4.00 & -10.38 & 2.19 & 145 & 2004 & 1 & 0.21 & 8.58 & -2.30 & 1.00 & 229 \\
\hline & 2 & 0.22 & 9.04 & -0.69 & 1.04 & 212 & & 2 & 0.03 & 0.84 & -1.16 & 1.00 & 352 \\
\hline & 3 & 0.06 & 1.11 & -2.43 & 5.45 & 224 & & 3 & 0.29 & 13.87 & -0.24 & 0.39 & 244 \\
\hline & 4 & 0.13 & 3.34 & 7.97 & 0.10 & 307 & & 4 & 0.22 & 16.71 & -0.02 & 1.39 & 293 \\
\hline \multirow[t]{4}{*}{1997} & 1 & -0.01 & 0.82 & 13.28 & 8.48 & 208 & 2005 & 1 & -0.03 & 0.25 & 4.67 & 4.05 & 305 \\
\hline & 2 & 0.05 & 4.51 & 0.79 & 4.99 & 309 & & 2 & 0.09 & 6.12 & -0.77 & 3.28 & 425 \\
\hline & 3 & 0.09 & 4.64 & 0.46 & 8.06 & 307 & & 3 & -0.02 & 5.67 & 1.62 & 1.34 & 352 \\
\hline & 4 & 0.05 & 2.49 & -26.93 & 2.86 & 254 & & 4 & 0.00 & 3.37 & -0.98 & 1.41 & 345 \\
\hline \multirow[t]{4}{*}{1998} & 1 & 0.07 & 4.74 & -0.65 & 0.75 & 232 & 2006 & 1 & 0.00 & 2.48 & -1.24 & 0.72 & 238 \\
\hline & 2 & 0.20 & 3.37 & 6.01 & 4.42 & 216 & & 2 & 0.09 & 6.36 & -0.38 & 0.88 & 314 \\
\hline & 3 & 0.16 & 18.64 & -3.56 & 1.47 & 164 & & 3 & -0.03 & 5.24 & 2.26 & 3.06 & 215 \\
\hline & 4 & -0.02 & 11.53 & 0.96 & 1.85 & 179 & & 4 & 0.07 & 0.94 & -0.36 & 1.46 & 245 \\
\hline \multirow[t]{4}{*}{1999} & 1 & 0.03 & 1.58 & -2.64 & 2.08 & 192 & 2007 & 1 & 0.02 & 0.27 & 0.42 & 1.37 & 180 \\
\hline & 2 & 0.13 & 8.87 & -1.23 & 1.13 & 139 & & 2 & 0.01 & 2.87 & 1.01 & 1.93 & 289 \\
\hline & 3 & 0.10 & 4.57 & -4.70 & 3.17 & 241 & & 3 & 0.06 & 3.83 & 0.33 & 3.99 & 236 \\
\hline & 4 & 0.15 & 5.62 & 6.37 & 3.04 & 218 & & 4 & 0.05 & 3.61 & -3.72 & 2.04 & 164 \\
\hline \multirow[t]{4}{*}{2000} & 1 & 0.21 & 9.03 & -0.02 & 0.80 & 242 & 2008 & 1 & 0.18 & 2.67 & 4.24 & 3.40 & 164 \\
\hline & 2 & 0.10 & 4.20 & -1.24 & 1.04 & 272 & & 2 & 0.05 & 24.65 & -0.52 & 0.42 & 138 \\
\hline & 3 & 0.11 & 3.03 & -1.89 & 3.63 & 280 & & 3 & 0.03 & 0.45 & 2.59 & 0.56 & 115 \\
\hline & 4 & 0.24 & 16.50 & -3.90 & 4.91 & 278 & & 4 & 0.83 & 6.36 & 9.15 & 1.44 & 90 \\
\hline \multirow[t]{4}{*}{2001} & 1 & 0.00 & 7.91 & 1.02 & 0.97 & 152 & 2009 & 1 & 0.22 & 10.04 & -3.97 & 0.73 & 72 \\
\hline & 2 & 0.04 & 3.07 & -5.89 & 6.15 & 303 & & 2 & -0.15 & 1.46 & 0.09 & 0.35 & 91 \\
\hline & 3 & 0.15 & 2.88 & -2.26 & 3.04 & 196 & & 3 & -0.27 & 1.96 & -0.15 & 1.32 & 79 \\
\hline & 4 & 0.20 & 3.38 & -4.02 & 1.51 & 249 & & 4 & -0.17 & 11.51 & 3.23 & 0.86 & 118 \\
\hline \multirow[t]{4}{*}{2002} & 1 & -0.02 & 7.02 & 1.46 & 1.42 & 241 & & & & & & & \\
\hline & 2 & 0.26 & 14.93 & -2.72 & 1.91 & 273 & & & & & & & \\
\hline & 3 & 0.14 & 15.23 & 0.86 & 0.42 & 201 & & & & & & & \\
\hline & 4 & 0.29 & 7.30 & -0.52 & 1.51 & 220 & & & & & & & \\
\hline
\end{tabular}

Note: This table reports the quarterly, first stage regression results (equation (4)). $\beta^{\text {lev }}\left(\beta^{\text {liq }}\right)$ measures the effect of a one percent increase in the borrower leverage (lender liquidity) ratio on the lending spread (in basis points) [dependent variable]. Values in bold indicate statistically significant coefficients (at the 1, 5, or 10 percent significance level). 
Table 3. Second stage estimation results

\begin{tabular}{|c|c|c|c|c|c|c|c|c|}
\hline & $\gamma^{b s}$ & $\psi$ & $\mathrm{R}-\mathrm{Sq}$ & N-obs & $\gamma^{l}$ & $\lambda$ & $\mathrm{R}-\mathrm{Sq}$ & N-obs \\
\hline \multirow[t]{2}{*}{ Nominal FFR } & 0.005 & -0.321 & 0.49 & 59 & 0.605 & 113.90 & 0.24 & 59 \\
\hline & $(3.62) * * *$ & $(4.44)^{* * *}$ & & & $(0.99)$ & $(1.64)$ & & \\
\hline \multirow[t]{2}{*}{ Real FFR } & 0.007 & 0.937 & 0.53 & 59 & 0.056 & 202.80 & 0.20 & 59 \\
\hline & $(4.41)^{* * *}$ & $(1.85)$ & & & $(0.67)$ & $(1.93)$ & & \\
\hline
\end{tabular}

Note: $\quad$ This table reports results from our second-stage regressions (5) and (6). Coefficient values for $\gamma^{\text {bs }}$ and $\gamma^{1}(\psi$ and $\lambda$ ) describe how the monetary policy stance [represented here by the nominal and real federal funds rate] (size of the US output gap) affects the sensitivity of the loan spread to borrower balance sheets and a bank's liquidity position, respectively. Significance levels: $* * *=1$ percent; $* *=5$ percent; $*=10$ percent. 
Table 4. Alternative measures of monetary policy stance

\begin{tabular}{|c|c|c|c|c|}
\hline & $\mathrm{CE}$ & $\mathrm{S}$ & $\mathrm{BR}$ & $\mathrm{BM}$ \\
\hline$\gamma^{b s}$ & 0.976 & 0.360 & 7.956 & 0.261 \\
\hline & $(2.88)^{* *}$ & $(2.84)^{* *}$ & $(1.82)^{*}$ & $(2.83)^{* *}$ \\
\hline & -4.432 & -3.755 & -7.398 & -3.692 \\
\hline & $(0.73)$ & $(0.68)$ & $(1.43)$ & $(0.66)$ \\
\hline $\mathrm{R}-\mathrm{Sq}$ & 0.44 & 0.44 & 0.37 & 0.44 \\
\hline $\mathrm{N}-\mathrm{obs}$ & 59 & 59 & 59 & 59 \\
\hline & & & & \\
\hline$\gamma^{l}$ & 13.570 & 4.750 & 84.530 & 3.457 \\
\hline & $(0.67)$ & $(0.80)$ & $(1.21)$ & $(0.83)$ \\
\hline$\lambda$ & 92.91 & 91.90 & 146.10 & 91.64 \\
\hline $\mathrm{R}-\mathrm{Sq}$ & $(1.07)$ & $(1.12)$ & $(1.92)$ & $(1.17)$ \\
\hline $\mathrm{N}-\mathrm{obs}$ & 0.20 & 0.22 & 0.26 & 0.22 \\
\hline $\mathrm{N}$ & 59 & 59 & 59 & 59 \\
\hline
\end{tabular}

Note: This table reports results from our second-stage regressions (5) and (6). Coefficient values for $\gamma^{\text {bs }}$ and $\gamma^{1}(\psi$ and $\lambda$ ) describe how the monetary policy stance (size of the US output gap) affects the sensitivity of the loan spread to borrower balance sheets and a bank's liquidity position, respectively. We use the following alternative measures for monetary policy stance: Christiano and Eichenbaum (1992) index (CE), Strongin (1995) index (S), an index constructed using the variation in borrowed reserves (BR), and the Bernanke and Mihov (1998) index (BM). Significance levels: $* * *=1$ percent; $* *=5$ percent; $*=10$ percent. 
Table 5. Comparing the strength of the lending and the balance sheet channels

\begin{tabular}{|c|c|c|c|c|c|c|}
\hline & Nominal FFR & Real FFR & CE & S & BR & BM \\
\hline$\gamma^{b s}$ & -0.158 & 1.102 & 71.480 & 34.000 & 207.200 & 25.080 \\
\hline & $(3.40)^{* * *}$ & $(2.29)^{* *}$ & $(10.68)^{* * *}$ & $(12.18)^{* * *}$ & $(3.33)^{* * *}$ & $(12.35)^{* * *}$ \\
\hline & & & & & & \\
\hline$\gamma^{l}$ & 0.037 & 0.015 & 1.738 & 0.674 & 8.609 & 0.495 \\
\hline & $(0.46)$ & $(0.31)$ & $(0.17)$ & $(0.16)$ & $(0.39)$ & $(0.16)$ \\
\hline
\end{tabular}

Note: This table reports results from our second-stage regressions (5) and (6), where we standardize our measures of the borrower leverage and lender liquidity ratio in the first stage to have a mean of zero and a standard deviation of one. Coefficient values for $\gamma^{\text {bs }}$ and $\gamma^{1}$ describe how the monetary policy stance affects the sensitivity of the loan spread to borrower balance sheets and a bank's liquidity position, respectively. We use the following alternative measures for monetary policy stance: nominal and real federal funds rate, Christiano and Eichenbaum (1992) index (CE), Strongin (1995) index (S), an index constructed using the variation in borrowed reserves (BR), and the Bernanke and Mihov (1998) index (BM). Significance levels: $* * *=1$ percent; $* *=5$ percent; $*=10$ percent. 
Table 6. Accounting for the first-stage measurement errors

\begin{tabular}{|c|c|c|c|c|c|c|}
\hline & Nominal FFR & Real FFR & $\mathrm{CE}$ & $\mathrm{S}$ & $\mathrm{BR}$ & $\mathrm{BM}$ \\
\hline \multicolumn{7}{|c|}{ Weighted Least Squares } \\
\hline \multirow{2}{*}{$\gamma^{b s}$} & 0.006 & 0.015 & 1.560 & 0.587 & 11.150 & 0.426 \\
\hline & $(4.40)^{* * *}$ & $(6.39)^{* * *}$ & $(4.47)^{* * *}$ & $(4.60) * * *$ & $(2.46)^{* *}$ & $(4.63)^{* * *}$ \\
\hline \multirow[t]{2}{*}{$\gamma^{l}$} & 0.373 & -0.143 & -0.007 & -1.028 & 15.520 & -0.670 \\
\hline & $(1.79)$ & $(1.44)$ & $(0.81)$ & $(0.81)$ & $(1.58)$ & -0.81 \\
\hline \multicolumn{7}{|c|}{ Bootstrap } \\
\hline & & & & & & \\
\hline \multirow{2}{*}{$\gamma^{b s}$} & 0.009 & 0.014 & 1.232 & 0.465 & 9.215 & 0.338 \\
\hline & $(3.17)^{* *}$ & $(3.24)^{* *}$ & $(3.41)^{* *}$ & $(3.38)^{* *}$ & $(2.55)^{*}$ & $(3.38)^{* *}$ \\
\hline \multirow{3}{*}{$\gamma^{l}$} & & & & & & \\
\hline & 0.533 & -0.091 & 8.612 & 2.658 & 59.361 & 1.920 \\
\hline & $(1.07)$ & $(0.82)$ & (1.17) & $(1.24)$ & $(1.50)$ & $(1.26)$ \\
\hline
\end{tabular}

Note: This table reports results from our second-stage regressions (5) and (6). In the weighted least squares regressions, we weigh each quarterly observation in the second-stage regressions with the $\mathrm{F}$ statistics associated with the coefficient values $\beta^{\text {lev }}$ and $\beta^{\text {liq }}$, respectively, from the first stage regressions. In the bootstrap regressions, we estimate quarterly coefficients for 100 random samples in our first-stage regression. We then stack these coefficients into 100 time-series vectors to form our dependent variable for the second-stage regression. We then average the resulting coefficient estimates and corresponding $\mathrm{F}$ statistics over the 100 different second-stage regressions to arrive at the results in the table. Coefficient values for $\gamma^{\text {bs }}$ and $\gamma^{1}$ describe how the monetary policy stance affects the sensitivity of the loan spread to borrower balance sheets and a bank's liquidity position, respectively. We use the following alternative measures for monetary policy stance: nominal and real federal funds rate, Christiano and Eichenbaum (1992) index (CE), Strongin (1995) index (S), an index constructed using the variation in borrowed reserves (BR), and the Bernanke and Mihov (1998) index (BM). Significance levels: $* * *=1$ percent; $* *=5$ percent; $*=10$ percent. 
Table 7. An alternative specification for measuring the balance sheet channel

\begin{tabular}{|c|c|c|c|c|c|c|}
\hline & Nominal FFR & Real FFR & CE & S & BR & BM \\
\hline$\gamma^{b s}$ & 0.003 & 0.006 & 0.563 & 0.236 & 3.510 & 0.174 \\
\hline & $(1.77)$ & $(4.62)^{* * *}$ & $(2.08)^{*}$ & $(2.12)^{*}$ & $(3.51)^{* * *}$ & $(2.13)^{*}$ \\
\hline$\psi$ & 0.753 & 3.034 & -3.492 & -3.640 & -3.977 & -3.700 \\
\hline & $(0.29)$ & $(0.92)$ & $(0.52)$ & $(0.59)$ & $(0.76)$ & $(0.60)$ \\
\hline R-Sq & 0.26 & 0.47 & 0.29 & 0.30 & 0.40 & 0.30 \\
\hline N-obs & 59 & 59 & 59 & 59 & 59 & 59 \\
\hline & & & & & & \\
\hline
\end{tabular}

Note: This table reports the results from our second-stage regressions (5) and (6), where the first-stage regressions are based on equation (7). In the first stage, the borrower leverage coefficients (not reported) indicate how the loan spread deviates from its mean when a borrower's leverage ratio deviates from the average leverage ratio of all of the bank's borrowers in that quarter. The second-stage coefficient values for $\gamma^{\text {bs }}(\psi)$ then describe how the monetary policy stance (size of the US output gap) affects the sensitivity of the loan spread to these (relative) borrower balance sheets. In addition to using the nominal and real federal funds rate as a proxy for the US monetary policy stance, we use the following alternative measures for monetary policy stance: Christiano and Eichenbaum (1992) index (CE), Strongin (1995) index (S), an index constructed using the variation in borrowed reserves (BR), and the Bernanke and Mihov (1998) index (BM). Significance levels: $* * *=1$ percent; $* *=5$ percent; $*=10$ percent. 
Table 8. Single stage estimation

\begin{tabular}{|c|c|c|c|c|c|c|}
\hline & Nominal FFR & Real FFR & $\mathrm{CE}$ & $\mathrm{S}$ & $\mathrm{BR}$ & $\mathrm{BM}$ \\
\hline \multirow{2}{*}{$\sum_{n=1}^{4} \beta_{n t}^{l e v}$} & 0.051 & 0.042 & 0.033 & 0.033 & 0.034 & 0.032 \\
\hline & $(14.19)^{* * *}$ & $(19.39)^{* * *}$ & $(25.37)^{* * *}$ & $(24.08)^{* * *}$ & $(22.90)^{* * *}$ & $(23.86)^{* * *}$ \\
\hline \multirow{2}{*}{$\sum_{n=1}^{4} \beta_{n t}^{l q}$} & -3.216 & -2.070 & -1.959 & -2.022 & -1.737 & -2.058 \\
\hline & $(7.28)^{* * *}$ & $(6.75)^{* * *}$ & $(5.90)^{* * *}$ & $(6.43)^{* * *}$ & $(4.50)^{* * *}$ & $(6.66)^{* * *}$ \\
\hline \multirow{2}{*}{$\sum_{k=1}^{8} \gamma_{k}$} & -0.607 & 8.968 & 229.000 & 88.690 & 1275.700 & 63.250 \\
\hline & $(38.82)^{* * *}$ & $(33.99) * * *$ & $(10.82)^{* * *}$ & $(10.40)^{* * *}$ & $(11.39)^{* * *}$ & $(10.40)^{* * *}$ \\
\hline \multirow{2}{*}{$\sum_{m=1}^{4} \sum_{k=m}^{m+7} \gamma_{m k}^{l e v}$} & -0.002 & 0.000 & 0.369 & 0.151 & 1.977 & 0.110 \\
\hline & $(10.12)^{* * *}$ & $(9.14)^{* * *}$ & $(10.76)^{* * *}$ & $(11.49)^{* * *}$ & $(8.14)^{* * *}$ & $(11.64)^{* * *}$ \\
\hline \multirow{2}{*}{$\sum_{m=1}^{4} \sum_{k=m}^{m+7} \gamma_{m k}^{l q}$} & 0.532 & -0.033 & 13.240 & 5.637 & 63.930 & 4.155 \\
\hline & $(5.66)^{* * *}$ & $(4.67)^{* * *}$ & $(7.57)^{* * *}$ & $(7.59)^{* * *}$ & $(7.87)^{* * *}$ & $(7.63)^{* * *}$ \\
\hline $\mathrm{R}-\mathrm{Sq}$ & 0.39 & 0.38 & 0.36 & 0.36 & 0.36 & 0.36 \\
\hline N-obs & 13,783 & 13,783 & 13,783 & 13,783 & 13,783 & 13,783 \\
\hline
\end{tabular}

Note: This table reports the single stage estimation results (equation (8)). The dependent variable is the lending spread of a loan. The $\beta_{n t}^{\text {lev }}$ coefficients refer to the borrower leverage ratio, the $\beta_{n t}^{l q}$ coefficients to the bank liquidity ratio, the $\gamma_{k}$ coefficients to monetary policy stance, the $\gamma_{m k}^{l e v}$ coefficients to the interactive term with monetary policy and the borrower leverage ratio, and the $\gamma_{m k}^{l q}$ coefficients to the interactive term with monetary policy and the bank liquidity ratio. We use the following alternative measures for monetary policy stance: nominal and real federal funds rate, Christiano and Eichenbaum (1992) index (CE), Strongin (1995) index (S), an index constructed using the variation in borrowed reserves (BR), and the Bernanke and Mihov (1998) index (BM). Significance levels: $* * *=1$ percent; $* *=5$ percent; $*=10$ percent. 